\title{
Corporate Governance and Firm Performance Before and After Financial Crisis 2006-2013: An Analysis of Financial Sector in Malaysia
}

\author{
Wan Fauziah Wan Yusoff \\ Faculty of Technology Management and Business \\ Universiti Tun Huseein Onn Malaysia \\ Mohamad Ismail Mohammed \\ Faculty of Technology Management and Business \\ Universiti Tun Huseein Onn Malaysia \\ Suleiman Mohammed Lame \\ Faculty of Technology Management and Business \\ Universiti Tun Huseein Onn Malaysia
}

\begin{abstract}
Corporate governance is one of the important determinants to improve the accountability of the company and enhance business prosperity. Hence good corporate governance has been major of concerned by investors to build up trust towards the company. In contrary, poor corporate governance frameworks in a firm faced the problem of lack of investor's confidence and failed to perform well in the achievements. This research aims to investigate the relationship between corporate governance and firm performance before and after the financial crisis for year 2006-2013 of the financial sector in Malaysia. The independent variables used in this study were independent directors, board size and CEO duality. While two dependent variables were chosen; earnings per share (EPS) and return on assets (ROA). Data was collected from the company's annual reports for the year 2006 and year 2013. This study revealed that the independent directors and CEO duality have not influence firm performance before and after financial crisis (2006-2013). However, board size found to have negative relationship with financial performance for both years. It can be concluded that there is no relationship between corporate governance before and after financial crisis. Corporate governance plays an important role regardless especially during the economic downturn.
\end{abstract}

JEL CODES: F34, G21 and G24

\section{INTRODUCTION}

Over the last two decades corporate governance has developed as an important mechanism to overseeing and control the firms. The need for good governance is evidenced by the various reforms and standards. Typically, in the economic and strategic management literature, corporate governance is considered as the institutions to mitigate the effects of agency problem exists in the organizations (Wan Fauziah Wan Yusoff \& Idris Adamu Alhaji, 2012).The recent global financial crisis has reinforced the importance of good corporate governance practices and structures. According to Prema-Chandra (2010), financial crisis related to the downturn of economic which caused large crumble of commodity trade. In fact, Malaysia's 
shares prices sharply decreased by $20 \%$ after the global financial crisis of the year 2007 until year 2009 (Prema-Chandra, 2010). The crisis shows a panic situation where the financial institutions or assets drop with out of expectation (Liliana, 2010),.Hence, corporate governance reformation after the financial crisis is a vital action to gain trust from shareholders and perform better achievement in the future.

In Malaysia, after the financial crisis in 2006/2007, Malaysian firms seek to enhance their corporate governance to gain back investors' confidents (Lai, 2004). This simply because good corporate governance will access to better performance and improve the confidence from investors (Claessen, 2002). From the view of Micah (2000), corporate governance can play in promoting robust and efficient financial systems which target to assist central banks and financial sector regulatory agencies to develop policies to promote effective corporate governance in financial sectors. Hence, until today the government has taken various initiatives and actions to ensure corporate governance in Malaysia in a well structured. This study analyse the relationship between corporate governance and firm performance before and after of the financial crisis focusing on financial sectors in Malaysia. The financial sector is chosen due to the stability of economic in any country rely highly upon the stability of financial sector of the country as well as the effectiveness of corporate governance of the sector.

\section{LITERATURE REVIEW AND HYPOTHESIS DEVELOPMENT}

Corporate governance can be defined as structures and processes for the position and control of companies (The World Bank, 2005). Shleifer and Vishny (1997), defined corporate governance as a way in which suppliers of finance corporations assure themselves of getting a return on their investment. According to Diane and John (2003) corporate governance is a set of mechanisms of both institutional and market-based to make decisions which maximize the value of the company to the owners. Good corporate governance target to enhance the business prosperity and accountability of the firms and attain the firm's objectives.

Despite the important roles of corporate governance, the relationship between corporate governance and firm performance is more "varied and complex" than can be covered by any single governance theory. Hence, various studies discovered a number of corporate governance components have influence firm performance such as number or percentage of independent directors, board leadership structure, board size, audit committee, board attributes and board meeting. For the purpose of this study only three corporate governance components that found to be the most important determinant of financial performance are reviewed; independent directors on the board; board leadership structure; and board size

\section{Independent Directors}

Independent directors(IDs) is defined as directors who monitor and delegate firm activities in reducing opportunistic managerial behaviors by monitoring and overseeing firm activities (Fama \& Jensen 1983, Brickley 1994). They are not full-time employees but capable of exercising independent judgement in board decision making (Mallin, 2004), and do not hold the shares or are not employed in the company (Jacqui, 2010). Because of their nature they are expected to bring independence into the board and add to the diversity of skills and expertise of directors to contribute and perform the tasks, independence, objectivity and expertise earned from their own fields (Abdullah, 2004).

Despite the advantages of having more independent directors on the board, prior studies documented mixed results. In Korea, Choi et al., (2007) found a positive effect on firm performance as a result of having more IDs on the company board. A similar situation was 
found in Ghana when Abor and Adjasi (2007) revealed that the presence of IDs on boards enhanced corporate competitiveness and provided new strategic outlooks for the firms. In contrast, Zong-Jun and Xiao-Lan (2006) revealed that a larger proportion of IDs is negatively associated with the probability of distress among firms in China. Likewise, Abdullah (2006) concluded from research into financially distressed and non-distressed companies listed on the Bursa Malaysia that non-executive IDs do not associated with a financially distressed status. Likewise, Ducvo and Thuy Phan (2013) discovered no link between independent director and firm performance.

It was argued that the negative impact of IDs on firm performance was because they are not able to ratify decisions made by powerful board members as they lack company information (Conger \& Lawler (2009). As a consequence they have some difficulties in understanding of their companies (Siladi, 2006). In fact, most developing countries, including Malaysia, the IDS were not selected based on their expertise and experience but more often for political reasons to legitimate business activities and for contacts and contracts (Haniffa \& Hudaib, 2006). Due to lack of expertise, lack of required skills and knowledge of company affairs, such directors would not be able to perform their roles effectively (Rahman \& Mohamed Ali, 2006). Based on the above review independent can have both negative and positive relationship with firm performance. Therefore, it is hypothesized that:

H1: There is a relationship between independent directors (IDs) and firm performance of financial sector in Malaysia before and after financial crisis 2006-2013.

\section{Board Size}

Board size is an important characteristic because it must fit well with the responsibilities and needs of the organizations. Board size refers to the number of directors sitting on the board (Levrau \& Van den Berghe, 2007). Board size has been found to vary between one country and another. For example, boards in Europe, in three countries (the UK, Switzerland and Netherlands) tend to have a small board size (fewer than ten board members), while other countries (e.g. Belgium, France, Spain, Italy and Germany) had a larger board size, i.e. between thirteen and nineteen members (Heidrick \& Struggles, 2007). However, Conger and Lawler (2009) argued that there is no magical or ideal size for a board and the right size for a board should be driven by how effectively the board can operate as a team.

The relationship between board size and performance may differ not just by firm specific characteristics but also by national institutional characteristics and countries. Therefore, the impact of board size on board and firm performance has been a matter of continuing debate. A number of empirical papers (Zahra, 1991; Dalton et al., 1999; Andres and Vallelado, 2008; Dey \& Chauhan, 2009; Fallatah \& Dickins, 2012) have examined the determinants of board size. All the above studies find that board size is positively related to firm size. For example, Andres and Vallelado (2008) revealed larger boards are more efficient in monitoring and advising functions and create more value for a firm. Hence, board size is expected to be greater when the need for information and hence board advice is high. Such needs are expected to increase with firm scale and complexity.

In contrast, many researchers provide empirical evidence of a negative relationship between board size and firm performance. Beiner et al., (2004) analysed the relationship between board size and the independent corporate governance mechanism of Swiss firms, and revealed a negative board size effect. Van Ees at al., (2008) performed a similar study on listed firms in the Netherlands and found that, even though the system of control mechanisms is different in 
the Netherlands. In addition, Dey and Chauhan (2009) revealed that, as board size increases, group dynamics, communication gaps and coordination cost increase.

These mixed results show that the relationship between board size and firm performance is inconclusive. One possible explanation for the conflicting findings is the endogenity of some factors in the firm performance model. For example, board size itself may be influenced by other governance factors such as board structure and board leadership (Colley et al. 2005). For these reasons, it can be concluded that there is no consensus about whether larger or smaller boards are better with respect to their impact on firm performance, irrespective of the type of performance indicators used. One of the argument the internal and external factors such as complexity of the organizational structure, industries, legal, economic and political environment play crucial determinant on the board size. The above discussion clearly lays down a platform to propose that board size may have positive or negative association with firm value, which gives support to develop first hypothesis.

H2: There is a relationship between board size and firm performance of financial sector in Malaysia before and after financial crisis 2006-2013.

\section{CEO Duality}

Agency theory argues for a clear separation of the responsibilities of the CEO and the chairman of the board and seems to prefer to have separate leadership structure (Fama \& Jensen, 1983; Jensen, 1993). If the CEO and the chairman of the board is the same person, there would be no other individual to monitor his or her actions and CEO will be very powerful and may maximize his or her own interests at the expense of the shareholders. The combined leadership structure promotes CEO entrenchment by reducing board monitoring effectiveness (Finkelstein \& D'Aveni, 1994). Thus, a separate leadership structure is recommended in order to monitor the CEO objectively and effectively.

Evidence on the relationship between CEO duality and firm performance are also mixed. Some studies provide evidence of a positive relationship between duality of roles and firm performance. Joshua (2007) found significant and positive associations between capital structure and CEO duality among Ghanaian films. Likewise, Tin Yan and Shu Kam (2008) found that the duality role is more effective because one individual can exercise full control over the firm and the person can provide a centralised focus on achieving organisational goals. In the US, Harjoto and Hoje (2008) found a positive relationship between CEO duality and firm values and performance.

On the contrary, Schmid and Zimmermann (2005), from their study of 152 Swiss firms, revealed no evidence of a systematic and significant difference in firm value between firms with a combination or firms with a separation function of chairman/CEO. In Egypt, Elsayed (2007) found that CEO duality had no impact on corporate performance. In Malaysia, many studies show that duality roles have no impact on the performance of Malaysian firms (Rahman \& Haniffa, 2005; Abdullah, 2006). Another study found that firms that had duality roles were not performing as well as their counterparts with separate board leadership (Rahman \& Haniffa, 2005). In addition, firms dominated by a single person led to financial reports being issued much later than those with separation of roles (Abdullah, 2004). This could be because centralisation of power resulting from the chairman-CEO duality could be detrimental to board effectiveness since the same person would manage and dominate board decisions. Overall, this review finds that the impact of dual roles on board and firm 
performance is different from one country to another. Both types of leadership structure are associated with similar effects on the firms and leading to the following hypotheses

H3: There a relationship between board leadership structure and firm performance of financial sector in Malaysia before and after financial crisis 2006-2013.

\section{RESEARCH DESIGN AND METHODOLOGY}

The main objective of this study is to investigation the relationship between three corporate governance components and firm performance of financial sector in Malaysia before and after financial crisis 2006-2013. Thus, this study utilized purely quantitative methods. To do so, this study utilized Bursa Malaysia databases to generate information from the annual reports of Malaysian PLCs, involving 60 companies under financial sector in Malaysia. Two years of data (2006 and 2013) were used to analyse the relationship of the dependent and dependent variables of the study. The selection of sample used in this study is similar to other corporate governance studies (i.e., Abdullah, 2004; Levrau \& Van den Berghe, 2007; Van Ees et al., 2008).

As mentioned in earlier sections in this study three independent variables representing corporate governance components. They are number of independent director on the board; board leadership structure; and board size. For dependent variables (firm performance) this study followed the predominant approach and used two financial measures of firm performance, Return on Equity (ROE) and Earnings per share (EPS). Table 1 summarizes the variables and their measurements used in this study.

Table 1: Definition of Variables

\begin{tabular}{|l|l|}
\hline \multicolumn{1}{|c|}{ Variables } & \multicolumn{1}{|c|}{ Measurement Scale } \\
\hline Board size & Total number of directors on board \\
\hline $\begin{array}{l}\text { Proportion of } \\
\text { Independent directors }\end{array}$ & $\begin{array}{l}\text { Ration of independent directors to total number of } \\
\text { directors on board }\end{array}$ \\
\hline CEO duality & $\begin{array}{l}\text { Indicator variables with the value of "0" if the role } \\
\text { of chairman and CEO combines and "1" } \\
\text { otherwise. }\end{array}$ \\
\hline $\begin{array}{l}\text { Earnings Per Share } \\
\text { (EPS) }\end{array}$ & $\begin{array}{c}\text { Net Income - Dividends on Preferred Stock } \\
\text { Return of Equity (ROE) }\end{array}$ \\
\hline
\end{tabular}

The research model of the study is shown in Figure 1.

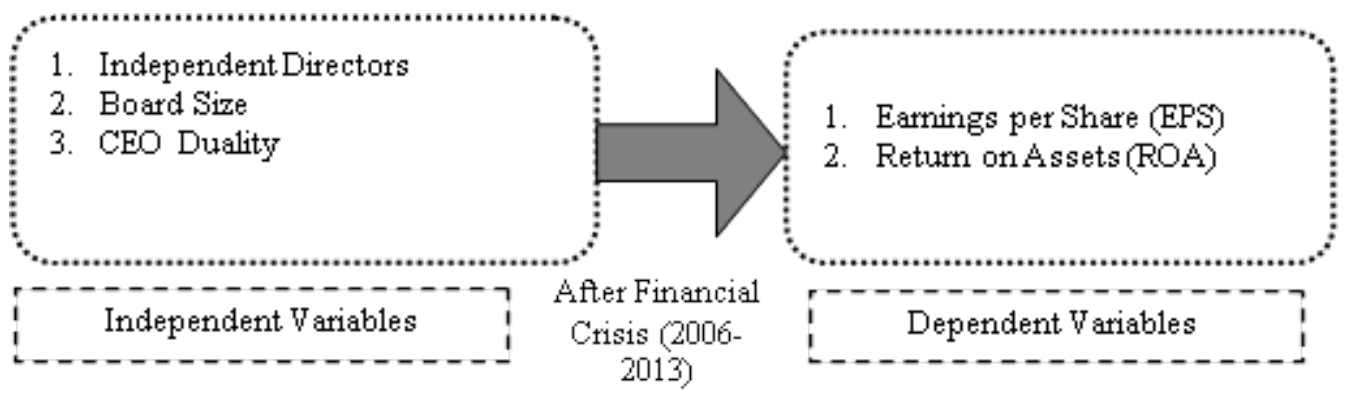

Figure 1 Research Model 


\section{RESULTS AND DISCUSSIONS}

Hypothesis 1: There is a relationship between independent directors (IDs) and firm performance of financial sector in Malaysia before and after financial crisis 2006-2013

Table 2 shows the relationship between independent directors and financial performance (ROA and ROE) of the study. Based on Table 2 the correlation coefficient value of each variable was below than 0.3 which indicated as weak relationship. Besides, the significant value $(\mathrm{p}$ value) was higher than 0.05 which indicated there is no relationship among independent directors and financial performance for financial sectors in Malaysia for both years (2006 and 2013).

Table 2: Correlation among Independent Directors and Financial Performance in Year 2006 and Year 2013

\begin{tabular}{|c|c|c|c|c|c|c|}
\hline & & & $\begin{array}{c}\text { Return On } \\
\text { Asset } \\
\text { (ROA) in } \\
\text { Year } 2006\end{array}$ & $\begin{array}{l}\text { Return On } \\
\text { Asset } \\
\text { (ROA) in } \\
\text { Year 2013 }\end{array}$ & $\begin{array}{l}\text { Earnings Per } \\
\text { Share (EPS) } \\
\text { in Year } 2006\end{array}$ & $\begin{array}{l}\text { Earnings } \\
\text { Per Share } \\
\text { (EPS) in } \\
\text { Year } 2013\end{array}$ \\
\hline \multirow[t]{5}{*}{$\begin{array}{l}\text { Spearm } \\
\text { an's rho }\end{array}$} & \multirow{3}{*}{$\begin{array}{l}\text { Independe } \\
\text { nt } \\
\text { Directors } \\
\text { in Year } \\
2006\end{array}$} & $\begin{array}{l}\text { Correlation } \\
\text { Coefficient }\end{array}$ & -.059 & -.203 & .026 & -.065 \\
\hline & & $\begin{array}{l}\text { Sig. } \\
\text { tailed) }\end{array}$ & .653 & .120 & .846 & .623 \\
\hline & & $\mathrm{N}$ & 60 & 60 & 60 & 60 \\
\hline & \multirow{2}{*}{$\begin{array}{l}\text { Independe } \\
\text { nt } \\
\text { Directors } \\
\text { in Year } \\
2013\end{array}$} & $\begin{array}{l}\text { Correlation } \\
\text { Coefficient }\end{array}$ & -.072 & .027 & .133 & .015 \\
\hline & & $\begin{array}{l}\text { Sig. } \\
\text { tailed) } \\
\mathrm{N}\end{array}$ & .583 & .839 & .309 & .909 \\
\hline
\end{tabular}

The result shows that independent directors do not influence firm performance of financial sector in Malaysia. The findings similar to many previous studies such as Abdullah (2006); Zong-Jun and Xiao-Lan (2006); Ducvo and Thuy Phan (2013) and many more. Large portion of independent directors would not affect the firm performance due to a number of reasons such as they were unfamiliar with the working environment in the firm (Raheja, 2005; Siladi, 2006), and unable to ratify decisions made by powerful board members as they lack company information (Conger \& Lawler (2009). One possible explanation to this as stated by Haniffa and Hudaib (2006) most of them were appointed not based on their expertise, rather for political reason.

Hypothesis 2: There is a relationship between board size and firm performance before of financial sector in Malaysia and after financial crisis 2006-2013

Table 3 shows the relationship between board size and firm performance for both return on asset (ROA) and earning per share (EPS) in year 2006 and year 2013. Negative value of correlation coefficient indicated a negative relationship and p-value lower than or equal to 0.05 indicated that there is relationship for both variables. The result showed that there is a negative relationship among board size and return on asset (ROA) in year 2013 where consists of p-value lower than 0.05. The result indicated that if the board size increased (decreased) then the return on asset (ROA) of company will be decreased (increased). It means that there is a relationship among board size and firm performance in year 2006 and in year 2013. 
Table 3: Correlation among Board Size and Financial Performance in Year 2006 and Year 2013

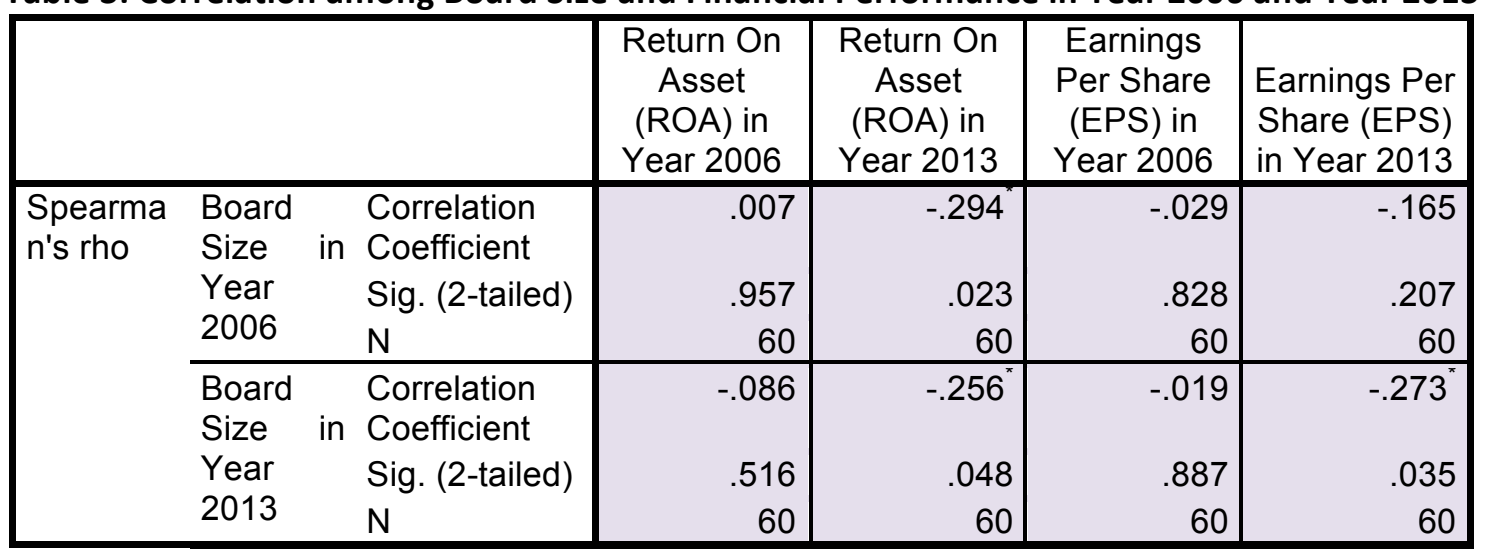

Correlation is significant at the 0.05 level (2-tailed).

The findings differ from previous studies to prove there is a relationship among board size and firm performance (Zahra, 1991, Andreas \& Valleledo, 2008: Fallatah \& Dickins, 2012). According to Colley at al., (2005) board size is influence by various factors such as organizational structure, industries, legal, economic and political requirements. Companies may need more board members when they are a need for more information due to expanding of their businesses. However, today many companies do not increase their board size as according to their performance (see Microsoft, Google, Walmart - maintain their board size for the past 10 years). Hence, the impact of board size and firm performance has been a matter of continuing debates until today.

Hypothesis 3: There is a relationship between CEO duality and financial performance of financial sector in Malaysia before and after financial crisis 2006-2013

Table 4 shows the correlation coefficient value of each variable was below than 0.3 which indicated as weak relationship. Besides, the significant value (p-value) found higher than 0.05 which indicated that there is no relationship among CEO duality and financial performance in year 2006 and in year 2013.

Table 4: Correlation among CEO Duality and Financial Performance in Year 2006 and Year 2013

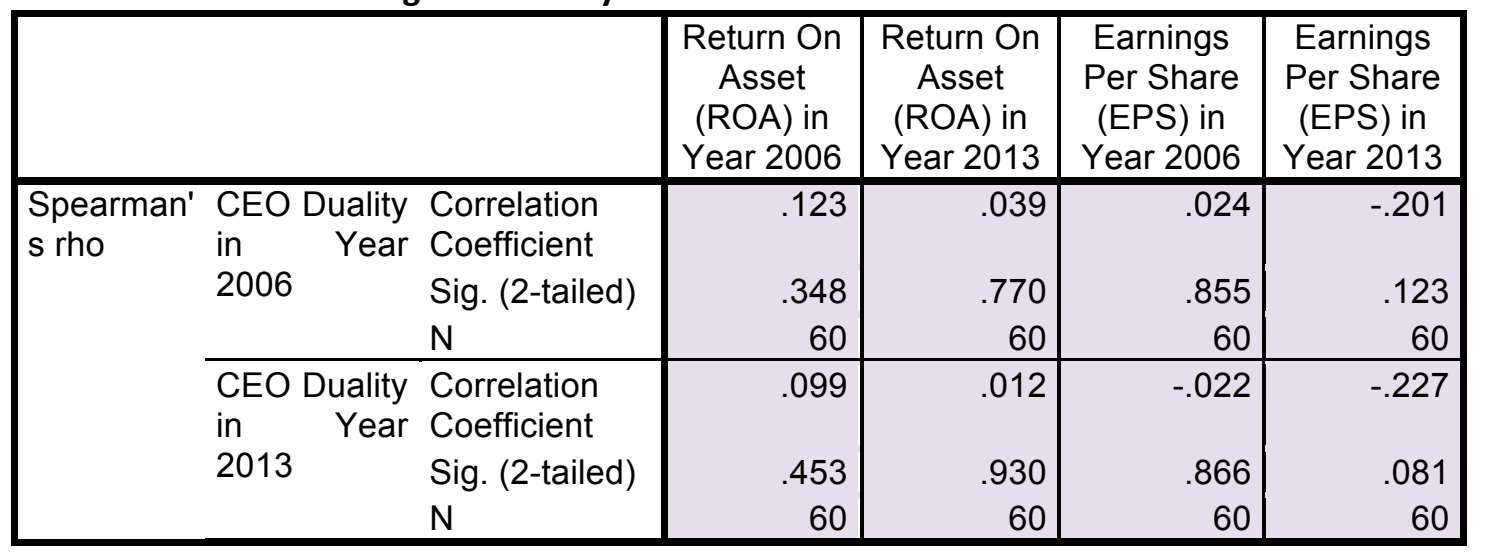

This study discovered that CEO duality do not influence firm performance of the financial sector in Malaysia before and after financial crisis 2006-2013. The findings similar to many previous studies (Schmid \& Zimmermann, 2005; Elsayed, 2007; Abdullah, 2006), which also discovered CEO duality has no significant impact on firm performance. This can be explain because the Central Bank of Malaysia rule and regulation prohibit all companies under the category of financial sector to appoint the same person as chairman and CEO. The rule and 
regulation generally to strengthen the corporate governance of the financial sector in Malaysia, particularly to gain investors' confidents

\section{CONCLUSION}

This paper reports and discusses the relationship between corporate governance and firm performance before and after financial crisis for 2006 and 2013 for financial sector in Malaysia. Three hypotheses were developed and tested (Independent directors, board size, and leadership structure) in relation to two performance indicators (ROE and EPS). This study revealed independent directors and CEO duality have not influence firm performance before and after financial crisis (2006-2012). However, board size found to have negative relationship with financial performance for both years, which is similar to the previous of in the literature. Many companies' had been failed due to the board's incapability to address the overall company performance in an effective and reliable manner. The main goal for this lies in the structure of the board, particularly in relation to the structure of the decision making process which needs to be transformed to enable companies to focus on sustaining high performance in the face of a rapidly changing environment. One of the factors for the high performance of companies that operate in this highly unstable environment is their diversity and adopting good corporate. The limitations of this study are only relying on two years data and involved only financial sector in Malaysia.

\section{ACKNOWLEDGEMENTS}

The authors would like to express our gratitude to all those who gave us the possibility to complete this study especially to Research Management Centre, Universiti Tun Hussein Onn Malaysia for providing research grant for this study.

\section{References}

Abdullah, S. N. (2006a). Board composition, audit committee and timeline of corporate financial reports in Malaysia. Journal of Corporate Ownership \& Control, 4(2), 33-45.

Abdullah, S. N. (2004). Board composition, CEO duality and performance among Malaysian listed companies. Corporate Governance International Journal of Business in Society, 4, p47-61.

Abor, J., Adjasi, C.K.D. (2007). Corporate governance and the small and medium enterprises sector: theory and implications. Corporate Governance, 7 (2), 12.

Andres, P. d., \& Vallelado, E. (2008). Corporate governance in banking: The role of the board of directors. Journal of Banking \& Finance, 32(12), 2570-2580.

Balasubramanian, N, Black BS, Khanna V (2010). The relations between firm-level corporate governance and market value, a case of India. Emerg. Mark. Rev. 11(4):319-340.

Beiner, S., Drobetz, W., Schmid, F., \& Zimmermann, H. (2004). Is board size an independent corporate governance mechanism? Kyklos, 57(3), 327-356.

Brickley, J. A., J. F. Coles, and R. L. Terry (1994). Outside Directors and the Adoptions of Poison Pills. Journal of Financial Economics 35, p371-390.

Cheng, S., Evans III J. H. and Nagarajan, N. (2008) Board size and firm performance: the moderating effects of the market for corporate control, Review of QuantitativeFinance and Accounting, forthcoming, DOI: 10.1007/s11156-0070074-3.

Choi, J.J., Park, S.W., Yoo, S.S. (2007). The value of outside directors: Evidence from corporate governance reform in Korea. Journal of Financial and Quantitative Analysis, 42(4), 941

Conger, J., \& Lawler, E. E. (2009). Sharing leadership on corporate boards: A critical requirement for teamwork at the top. SSRN eLibrary. Retrieved from http://ssrn.com/paper=1313353. 
Coles, J. L., Daniel, N. D. and Naveen, L. (2008) Boards: Does one size fit all? Journal of Financial Economics, 87, 329356.

Colley, J. L., Doyle, J., Dogan, G. L., \& Stettinius, W. (2005). What is corporate governance? New York: Mc Graw Hill. Claessens, S., Djankov, S. and Fan, J. P. H. (2002). Disentangling the Incentive and Entrenchment Effects of Large Shareholders. Journal of Finance, 57 (6), 2741-71.

Dalton, D. R., Daily, C. M., Johnson, J., \& Ellastrad, A. (1999). Number of directors and financial performance: A Meta analysis. In M. Ezzamel (Ed.), Governance, directors and boards. USA: Elgar Reference Collection.

Dey, D. K., \& Chauhan, Y. K. (2009). Board composition and performance in Indian firms: A comparison. ICFAI Journal of Corporate Governance, 8(2), 7-19.

Diane K. Denis and John. J.McConnell (2003). International Corporate Governance. United States: Purdue University Ducvo and Thuy phan (2013). Corporate governance and Firm Performance: Empirical Evidence from Vietnam. Open University, Ho Chi Minh City.

Elsayed, K. (2007). Does CEO duality really affect corporate performance? Corporate Governance: An International Review, 15(6), 1203-1214.

Fallatah, Y., \& Dickins D., (2012). Corporate Governance and Firm Performance and Value in Saudi Arabia. African Journal of Business Management. Vol. 6 (36), pp. 10034.

Fama, E. F. and M. Jensen, (1983) Separation of Ownership and Control. Journal of Law and Economics, 26, p 301-325.

Haniffa, R. M. (1999). Culture, Corporate Governance and Disclosure in Malaysia Corporations. Thesis from University of Exeter, UK.

Harjoto, M. A., \& Hoje, J. (2008). Board leadership and firm performance. Journal of International Business \& Economics, 8(3), 143-154.

Heidrick \& Struggles. (2007). 10th annual corporate board effectiveness study. Retrieved from http://www.heidrick.com/NR/rdonlyres/723D125E-9746-4486-829A-

D49A8AF0832B/0/HS_BoardEffectivenessStudy0607.pdf.

Jacqui Baumgardt (2010). Non-executive Directors: Why, Who and How? Chartered Secretaries Southern Africa.

Joshua, A. (2007). Corporate governance and financing decisions of Ghanaian listed firms. Corporate Governance, 7(1).

Korn/Ferry International, \& Egan Associates. (2007). Board of director study in Australia and New Zealand. Retrieved from http://www.kornferry.com/Publication/10003.

Lai, Y. D. (2004). Corporate Governance in Malaysia: The Underlying Chinese Business Culture. Adelaide, South Australia: University of South Australia.

Levrau, A. and Van den Berghe, L. A. A. (2007). Corporate governance and board effectiveness: Beyond formalism. ICFAI Journal of Corporate Governance, 6(4), p58-85.

Liliana Bunescu (2010). Global Financial Crisis and Reverberations on Capital Market. Romanian Economic and Business Review, vol. 5, No. 3, p226-235.

Mallin, C. (2004). Corporate Governance. Great Britain: Oxford University Press

Roszaini Haniffa and Mohammad Hudaib (2006). Corporate Governance Structure and Performance of Malaysian Listed Companies. Journal of Business, Finance and Accounting, vol. 33, p1034-1062.

The Word Bank (2005). Corporate governance country assessment: Malaysia Report onthe Observance of Standards and Codes (ROSC) Corporate Governance.Report No. 38970. Retrieved from http://www.worldbank.org/ifa/rosc_cg_html.

Tin Yan, L., \& Shu Kam, L. (2008). CEO duality and firm performance: Evidence from Hong Kong. Corporate Governance, $8(3), 299-316$.

Schmid, M. M., \& Zimmermann, H. (2005). Should chairman and CEO be separated? Leadership structure and firm performance in Switzerland SSRN eLibrary. Retrieved from http://ssrn.com/paper=696381. 
Yusoff, W. F. W., Mohammed, M. I., \& Lame, S. M. (2015). Corporate Governance and Firm Performance Before and After Financial Crisis 20062013: An Analysis of Financial Sector in Malysia. Archives of Business Research, 3(3), 1-10.

Valenti, M., Luce, R. and Mayfield, C. (2011). The Effects of Firm Performance on Corporate Governance. Management Research Review, vol. 34, No. 3, p266-283.

Van Ees, H., van der Laan, G., \& Postma, T. J. B. M. (2008). Effective board behaviour in The Netherlands. European Management Journal, 26(2), 84-93.

Wan Fauziah Wan Yusoff \& Idris Adamu Alhaji (2012). Corporate governance and firm performance in Malaysia, International Journal of Trend and Management Development Studies. Vol 1, Issue 1, page 43-65, ISSN $2319-7893$

Zahra, (1991). Board of directors and corporate financial performance. Journal of management, 15(2), 291-334.

Zong-Jun, W., \& Xiao-Lan, D. (2006). Corporate governance and financial distress.

Chinese Economy, 39(5), 5-27. 